V. S. Zaychenko, O. A. Ruban, Ju. S. Masliy, N. A. Gerbina

National University of Pharmacy

\title{
JUSTIFICATION OF SURFACE-ACTIVE SUBSTANCES CHOICE IN COMPOSITION OF SUPPOSITORIES FOR TREATMENT OF PROSTATE GLAND BENIGN DISEASES
}

Introduction. Prevention and treatment of benign prostatic diseases remain one of the pressing problems of modern medicine. Rectal suppositories are one of the main dosage forms used in urological practice. In order to provide the necessary organoleptic, physico-chemical, technological and osmotic properties, into their composition surfactants are introduced.

The aim of this work was to select the optimal surfactant and to substantiate its concentration in the suppositories with indole-3-carbinol and meloxicam.

Materials and methods. As the research objects have been selected: the carrier - PEO-base, emulsifiers - Montanox 80, Lanette SX, Cremophor RH-40, Myverol 18-04K NF, soy lecithin. The investigation of organoleptic (appearance, absence of inclusions and stratifications, homogeneity at the cut), physico-chemical ( $\mathrm{pH}$, time of decomposition), technological (resistance to destruction) and osmotic (dialysis through a semipermeable membrane) properties of the suppositories by the methods of SPU has been performed.

Results and discussion. Model specimens of suppositories with Montanox 80, Lanette SX and soy lecithin comply with the requirements of the SPU for all quality indices. In order to reduce the osmotic activity of the developed suppositories, the addition of Montanox 80 emulsifier in the amount of $3 \%$ was found to be most appropriate, which would not result in dehydration and overdrying of the rectum mucosa.

Conclusions. Experimental researches have established that the optimal surfactant in the composition of the suppositories with indole-3-carbinol and meloxicam, which provides the necessary qualitative characteristics and reduces the hyperosmotic properties of the polyethylene oxide base, is Montanox 80 in the amount of $3 \%$.

Key words: benign diseases of prostate gland; rectal suppositories; PEO-base; surface-active substances; organoleptic; physico-chemical and technological properties; osmotic activity

\section{В. С. Зайченко, О. А. Рубан, Ю. С. Маслій, Н. А. Гербіна}

Обгрунтування вибору поверхнево-активних речовин у складі супозиторіїв для лікування доброякісних захворювань передміхурової залози

Вступ. Профілактика і лікування доброякісних захворювань передміхурової залози залишаються однією 3 актуальних проблем сучасної медицини. Ректальні супозиторії є однією з основних лікарських форм, що використовуються в урологічній практиці. 3 метою надання необхідних органолептичних, фізико-хімічних, технологічних і осмотичних властивостей до їх складу вводяться поверхнево-активні речовини (ПАР).

Метою даної роботи $є$ вибір оптимальної ПАР та обгрунтування ії̈ концентрації у складі супозиторіїв $з$ індол-3-карбінолом і мелоксикамом.

Матеріали та методи. Як об’єкти дослідження обрані: носій - ПЕО-основа, емульгатори - Montanox 80, Lanette SX, Cremophor RH-40, Myverol 18-04K NF, лецитин соєвий. Проведено дослідження органолептичних (зовнішній вигляд, відсутність вкраплень та розшарувань, однорідність на зрізі), фізико-хімічних (рН, час розпадання), технологічних (стійкість до руйнування) і осмотичних (метод діалізу крізь напівпроникну мембрану) властивостей супозиторіїв за методиками ДФУ.

Результати та їх обговорення. Модельні зразки супозиторіїв з Montanox 80, Lanette SX та лецитином соєвим за всіма показниками якості відповідали вимогам ДФУ. Для зниження осмотичної активності супозиторіїв, що розробляються, найбільш доцільним виявилось додавання емульгатора Montanox 80 у кількості 3 \%, що не призводитиме до зневоднення та пересушування слизової оболонки прямої кишки.

Висновки. Експериментальними дослідженнями встановлено, що оптимальною ПАР у складі супозиторіїв з індол-3-карбінолом і мелоксикамом, яка забезпечує необхідні якісні характеристики та зменшує гіперосмотичні властивості поліетиленоксидної основи, є Montanox 80 у кількості $3 \%$.

Ключові слова: доброякісні захворювання передміхурової залози; ректальні супозиторії; ПЕО-основа; поверхнево-активні речовини; органолептичні; фізико-хімічні і технологічні властивості; осмотична активність

\section{В. С. Зайченко, Е. А. Рубан, Ю. С. Маслий, Н. А. Гербина}

Обоснование выбора поверхностно-активных веществ в составе суппозиториев для лечения доброкачественных заболеваний предстательной железы

Введение. Профилактика и лечение доброкачественных заболеваний предстательной железы остаются одной из актуальных проблем современной медицины. Ректальные суппозитории являются одной из основных лекарственных форм, используемых в урологической практике. С целью предоставления необходимых органолептических, физико-химических, технологических и осмотических свойств в их состав вводятся поверхностноактивные вещества (ПАВ).

Целью данной работы является выбор оптимального ПАВ и обоснование его концентрации в составе суппозиториев с индол-3-карбинолом и мелоксикамом. 
Материалы и методы. В качестве объектов исследования были выбраны: носитель - ПЭО-основа, эмульгаторы - Montanox 80, Lanette SX, Cremophor RH-40, Myverol 18-04K NF, лецитин соевый. Проведено исследование органолептических (внешний вид, отсутствие вкраплений и расслоений, однородность на срезе), физико-химических (pH, распадаемость), технологических (устойчивость к разрушению) и осмотических (метод диализа через полупроницаемую мембрану) свойств суппозиториев по методикам ГФу.

Результаты и их обсуждение. Модельные образцы суппозиториев c Montanox 80, Lanette SX и лецитином соевым по всем показателям качества соответствовали требованиям ГФУ. Для снижения осмотической активности разрабатываемых суппозиториев наиболее целесообразным явилось добавление эмульгатора Montanox 80 в количестве 3 \%, что не приведет к обезвоживанию и пересушиванию слизистой оболочки прямой кишки.

Выводы. Экспериментальными исследованиями установлено, что оптимальным ПАВ в составе суппозиториев с индол-3-карбинолом и мелоксикамом, обеспечивающим необходимые качественные характеристики и уменьшающим гиперосмотические свойства полиэтиленоксидной основы, является Montanox 80 в количестве 3 \%.

Ключевые слова: доброкачественные заболевания предстательной железы; ректальные суппозитории; ПЭО-основа; поверхностно-активные вещества; органолептические; физико-химические и технологические свойства; осмотическая активность

\section{INTRODUCTION}

The growth of benign prostatic diseases among men over 30 years is a serious problem, the solution of which depends on the availability and implementation of modern medical products in the medical practice [1-3]. It is known that the result of treatment depends not only on the correctly chosen medicinal product, but also on the way of its administration. Many clinicians prefer rectal administration, noting its positive aspects such as: increasing the speed of absorption and local effect of drugs on inflammation, prolonged therapeutic effect, reduced levels of side effects, the possibility of combination of several drugs, etc. [4-6]. In this regard, the aim of our research was to develop the composition and technology of rectal suppositories containing as APIs indole-3-carbinol and meloxicam [7].

The main step in creating a new dosage form is the choice of pharmaceutical factors, since by their regulation it is possible to change the pharmacokinetic parameters, biological availability and pharmacological effect [8].

As is known, the properties of drugs in the form of suppositories are most affected by the presence in their composition of surface-active substances (surfactants). According to literature, they can exacerbate, diminish or change the nature of APIs action. The introduction of surfactants in the base provides a high degree of API dispersion and solubility, increases the interaction zone, reducing the surface tension between the carrier of the active substance and the mucous membrane of the rectum, which improves the intensity of diffusion and resorption of medicinal substances, and also contributes to their better absorption [9-11].

The aim of these studies was to substantiate the choice of surfactants in the composition of suppositories for the treatment of benign prostatic diseases.

\section{MATERIALS AND METHODS}

The following objects were selected for research: the suppository base - an alloy of polyethylene oxides with a molecular weight of 400 and 1500; surfactants - Montanox 80 (Seppic, USA), Lanette SX (Basf, Germany), Cremophor RH-40 (Basf Personal Care and Nutrition GmbH,
Germany), Myverol 18-04K NF (Kerry Group, Malaysia) and soy lecithin (Kanav Aronomy, India).

Suppositories were prepared by pouring. Subsequently, the following indices were assessed: organoleptic (appearance, absence of inclusions and stratifications, homogeneity at the cut), physical and chemical ( $\mathrm{pH}$, time of decomposition) and technological (resistance to destruction). The study of model samples of suppositories was carried out in accordance with the SPU according to standard methods [12].

The study of surfactants influence on the osmotic properties of suppositories was carried out by dialysis through a semipermeable membrane with subsequent determination of the mass of the sample at regular intervals of time for 7 hours [13-14].

\section{RESULTS AND DISCUSSION}

In order to select the optimal emulsifier, suppositories were made on a polyethylene oxide basis, which was selected on the basis of previous pharmacological studies, with the addition of various surfactants: Montanox 80 (polysorbate-80), Lanette SX (emulsifier No. 1), Cremophor RH-40 (PEG-40 hydrogenated castor oil), Myverol 18-04K NF (distilled monoglycerides) and soya lecithin at a concentration of $3.0 \%$ of total weight. The influence of surfactant on the properties of model samples of suppositories was studied. The obtained results of the research are presented in the Table.

As can be seen from the data presented in Table, all model samples met the requirements for the quality of suppositories in terms of average weight and resistance to destruction. However, it should be noted that suppositories with Myverol 18-04K NF had a slightly higher acidity than the rest of the samples, in addition, they were heterogeneous.

Suppositories that contained Cremophor emulsifier RH-40 also did not meet the requirements in appearance and time of disintegration. Thus, for further research, model suppository samples with Montanox 80, Lanette SX and soy lecithin have been chosen.

An important specific indicator that characterizes certain properties of drugs in the form of suppositories for 
INFLUENCE OF SURFACTANT ON THE PROPERTIES OF MODEL SAMPLES OF SUPPOSITORIES

\begin{tabular}{|c|c|c|c|c|c|}
\hline \multirow{2}{*}{$\begin{array}{l}\text { Name of } \\
\text { surfactant }\end{array}$} & \multirow[b]{2}{*}{ Appearance } & \multicolumn{4}{|c|}{ Quality indices } \\
\hline & & $\begin{array}{l}\text { Average } \\
\text { weight, } \mathrm{g}\end{array}$ & \begin{tabular}{|c|}
$\begin{array}{c}\mathrm{pH} \text { of aqueous } \\
\text { solution }\end{array}$ \\
\end{tabular} & \begin{tabular}{|c|} 
Time of \\
disintegration, $\min$ \\
\end{tabular} & $\begin{array}{c}\text { Resistance to } \\
\text { destruction, kg }\end{array}$ \\
\hline Montanox 80 & $\begin{array}{c}\text { Suppositories of torpedo shape, } \\
\text { homogeneous, light yellow, with a weak } \\
\text { specific odor. No inclusions are observed } \\
\text { on the cut }\end{array}$ & $2.95 \pm 0.03$ & $6.58 \pm 0.04$ & $43 \pm 3$ & $3.0 \pm 0.1$ \\
\hline Lanette SX & $\begin{array}{c}\text { Suppositories of torpedo shape, } \\
\text { homogeneous, light yellow, with a weak } \\
\text { specific odor. No inclusions are observed } \\
\text { on the cut }\end{array}$ & $2.96 \pm 0.03$ & $6.55 \pm 0.05$ & $45 \pm 2.5$ & $3.2 \pm 0.1$ \\
\hline $\begin{array}{l}\text { Cremophor } \\
\text { RH-40 }\end{array}$ & $\begin{array}{l}\text { Suppositories of torpedo shape, light } \\
\text { yellow, with a weak specific odor. On the } \\
\text { cut inclusions are observed }\end{array}$ & $2.99 \pm 0.04$ & $6.74 \pm 0.04$ & $62 \pm 3$ & $3.5 \pm 0.1$ \\
\hline $\begin{array}{l}\text { Myverol 18- } \\
\text { 04K NF }\end{array}$ & $\begin{array}{c}\text { Suppositories of torpedo shape, } \\
\text { light yellow, without a specific odor. } \\
\text { Heterogeneous }\end{array}$ & $3.05 \pm 0.03$ & $7.08 \pm 0.06$ & $52 \pm 3$ & $3.1 \pm 0.1$ \\
\hline Soy lecithin & $\begin{array}{l}\text { Suppositories of torpedo shape, } \\
\text { homogeneous glossy, light yellow, with } \\
\text { a weak specific odor. There are no } \\
\text { inclusions on the cut }\end{array}$ & $3.06 \pm 0.04$ & $6.25 \pm 0.05$ & $44 \pm 3$ & $3.05 \pm 0.1$ \\
\hline
\end{tabular}

Note. $\mathrm{n}=5 ; \mathrm{P}=95 \%$.

the treatment of benign prostatic diseases is their osmotic activity. It should be noted that the value of this indicator depends mainly on the type of suppository base and, if necessary, can be corrected by the addition of a surfactant [13].

It is known that one of the disadvantages of the polyethylene oxide base is its high osmotic activity, which can lead to dehydration of cells at contact of the base with the affected inflammatory sites [14-15]. The hydrophilic part of a surfactant is capable of forming hydrogen bonds to the active centers of polyethylene oxide, and with its long lipophilic "tail" shield a part of its hydroxyl groups, thereby blocking access of water molecules to them. This is what causes the decrease of the PEO-base osmotic activity.
Therefore, the next step in our work was the final selection of surfactant and determination of its amount in order to reduce the hyperosmotic properties of the suppository base.

When choosing a surfactant, samples of suppositories without and with the addition of such emulsifiers as Montanox 80, Lanette SX and soy lecithin at a concentration of $3 \%$ were studied.

The study of osmotic activity was carried out by dialysis through a semipermeable membrane with the following determination of the weight of the sample at equal intervals of time for 7 hours. The research results are shown in Fig. 1.

The conducted studies have shown (Fig. 1) that the smallest osmotic activity has a sample with Montanox 80 -

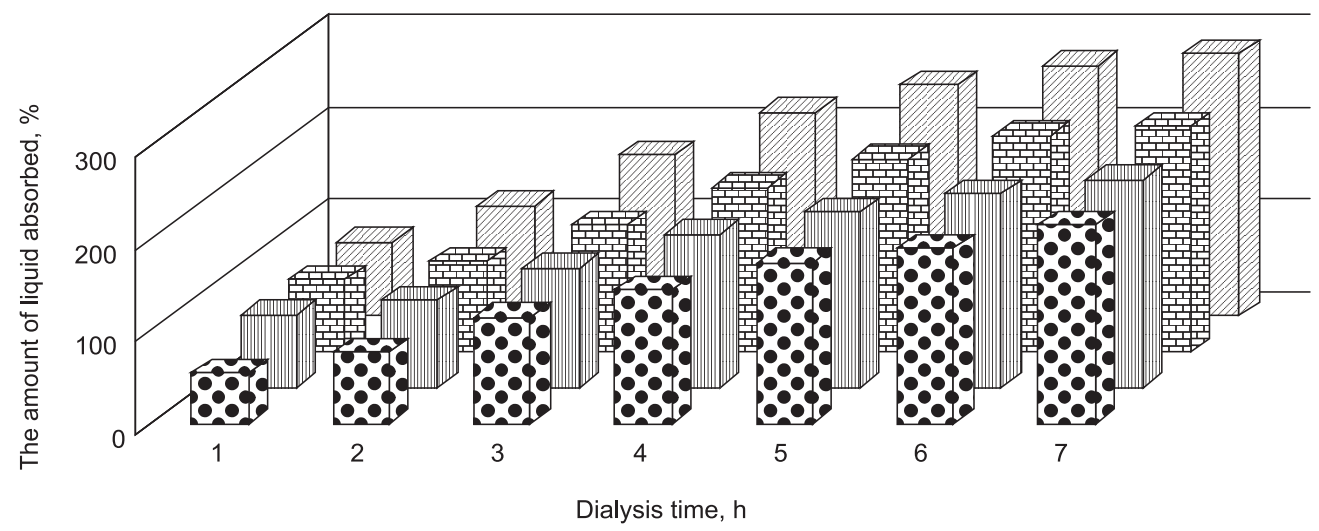

$\begin{array}{ll}\text { Suppositories + Montanox } 80 & \text { 圖 Suppositories + Lanette SX } \\ \text { Suppositories + soy lecithin } & \text { Suppositories without surfactant }\end{array}$

Fig. 1. Kinetics of water absorption by model samples from dialysis time 


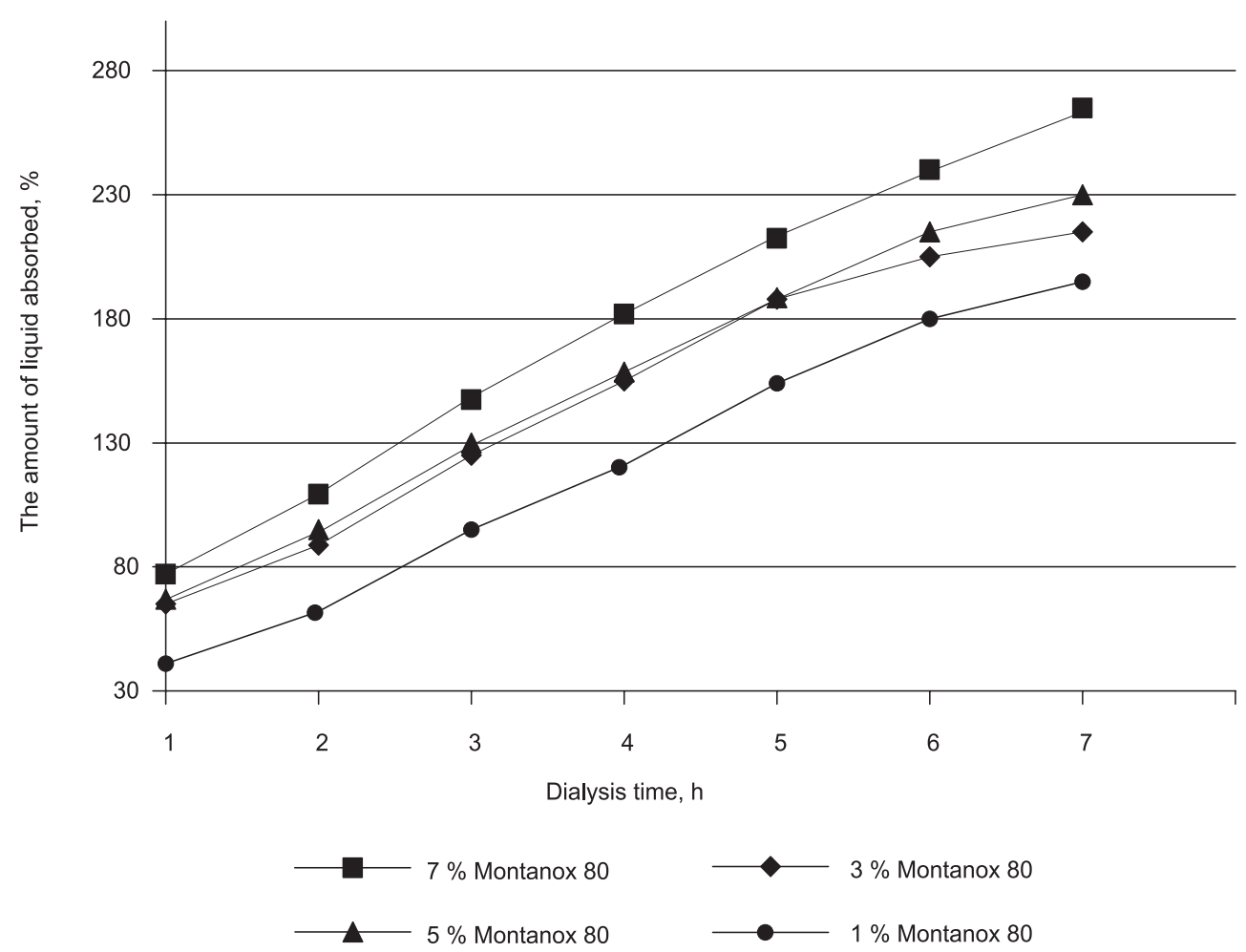

Fig. 2. The dependence of the amount of absorbed liquid on the dialysis time of samples with different contents of Montanox 80

the amount of absorbed fluid was $215 \%$ for 7 hours of research. The amount of absorbed liquid in samples with other surfactants (Lanette SX, soy lecithin) and without emulsifiers was within the range of $225-285 \%$.

Thus, on the basis of the conducted studies it can be concluded that to reduce the hyperosmotic properties of the polyethylene oxide base, it is most appropriate to add emulsifier Montanox 80.

The next step in our research was to find the optimal concentration of Montanox 80 needed to reduce the osmotic activity of suppositories. To do this, samples were prepared with the addition of 1, 3, 5 and $7 \%$ Montanox 80 to the PEO-base. The results are presented in Fig. 2.

The results of the study have shown (Fig. 2) that the addition of Montanox 80 at a concentration of $1 \%$ did not significantly reduce the osmotic activity - the total amount of absorbed water for 7 hours of the experiment was $195 \%$. Adding Montanox 80 at concentrations of $3 \%$ and $5 \%$ provided absorption of water at almost the same level - $215 \%$ and $230 \%$ respectively. Addition of Montanox 80 at a concentration of $7 \%$ proved to be inappropriate as it resulted in loss of mechanical stability of suppositories.

\section{CONCLUSIONS}

1. The analysis of scientific literature has established the importance of developing a domestic medicinal product in the form of rectal suppositories for the treatment of benign prostatic diseases.

2. It has been established that one of the most important issues in the creation of suppositories on the PEO-base is the choice of emulsifiers in their composition, as which Montanox 80, Lanette SX, Cremophor RH-40, Myverol 18-04K NF and soy lecithin have been used.

3. The influence of surface-active substances on the organoleptic, physical-chemical, technological and osmotic properties of model samples of suppositories has been studied.

4. Based on the data obtained, as a surfactant Montanox 80 was chosen in a concentration of $3 \%$, which allowed obtaining the most aggregately stable systems and provided the necessary osmotic activity for the suppositories being developed.

Conflict of Interests: authors have no conflict of interests to declare.

\section{REFERENCES}

1. Болезни предстательной железы / ред. Ю. Г. Аляев. - М. : ГЭОТАР-Медиа, 2009. - 240 с.

2. Haverkamp, J. Prostate inflammation and its potential impact on prostate cancer : a current review / J. Haverkamp, B. Charbonneau, T. L. Ratliff // J. Cell. Biochem. - 2008. - Vol. 103, Issue 5. - P. 1344-1353. doi: 10.1002/jcb.21536

3. Филиппович, В. А. Доброкачественная гиперплазия предстательной железы : современный подход к медикаментозной терапии / В. А. Филиппович // Журн. Гродненского гос. мед. университета. - 2008. - № 1. - С. 93-101.

4. Проблемы создания и стандартизации суппозиториев на современном этапе / Т. А. Панкрушева, Л. Н. Ерофеева, Т. В. Орлова и др. // Курский научно-практический вестник «Человек и его здоровье». - 2016. - № 2. - С. 108-112. 
5. Дзюба, А. С. Современное состояние и перспективы развития рынка суппозиториев / А. С. Дзюба, Е. О. Трофимова // Фармация. - 2014. № 3. - С. 27-30.

6. Орлова, Т. В. Современные ректальные, вагинальные и уретральные лекарственные формы / Т. В. Орлова // Вестник Воронежского гос. университета. Серия : Химия. Биология. Фармация. - 2014. - № 1. - С. 126-133.

7. Justification for the Composition and Method of Active Pharmaceutical Ingredients Administration at the Development of Suppositories for the Treatment of Benign Prostate Gland Diseases / V. S. Zaichenko, O. A. Ruban, Ju. S. Maslii, N. A. Gerbina // Asian J. of Pharmac. -2017. - Vol. 11, Issue 2. - P. 129-134.

8. Фармацевтическая разработка : концепция и практические рекомендации. Научно-практическое руководство для фармацевтической отрасли / под ред. С. Н. Быковского. - М. : Перо, 2015. - 472 с.

9. Изучение влияния эмульгатора на высвобождение глицина и ибупрофена из суппозиториев / Р. А. Абрамович, А. Н. Воробьев, И. А. Елагина, Н. И. Синицына // Научные ведомости Белгородского гос. университета. Серия : Медицина. Фармация. - 2012. - Т. 18, № 10-3 (129). C. 101-104.

10. Effect of the surfactant on the availability of piroxicam as a poorly hydrosoluble drug from suppositories. Pharmazie / M. Dal Zorro, E. Franceschinis, A. Punchina, N. Realdon. - 2012. - Vol. 1. - P. 37-45.

11. Орлова, Т. В. Вспомогательные вещества в технологии суппозиториев и научно-методические подходы к их выбору / Т. В. Орлова, Т. А. Панкрушева. - Курск : КГМУ, 2013. - 160 с.

12. Державна фармакопея України : в 3-х т. / Державне підприємство «Український науковий фармакопейний центр якості лікарських засобів». - 2-е вид. - Х. : Український науковий фармакопейний центр якості лікарських засобів, 2015. - Т. 1. - 1128 с.

13. Touitou, E. New hydrophilic vehicles enabling rectal and vaginal absorbtion / E. Touitou, M. Donbrow, E. Azaz // Drug Delivery. - 2005. - Vol. 1. P. 399-407.

14. Изучение влияния вида носителя и поверхностно-активных веществ на биофармацевтические свойства суппозиториев с празиквантелом / Д. М. Романина, В. В. Гладышев, А. П. Лисянская, И. Л. Кечин // Акт. питання фарм. і мед. науки та практики. - 2016. - № 3 (22). C. $23-27$.

15. Орлова, Т. В. Выбор суппозиторной основы в технологии суппозиториев / Т. В. Орлова, Т. А. Панкрушева // Фармация. - 2014. - № 1. - С. $34-38$.

\section{REFERENCES}

1. Aliaev, Yu. G. (2009). Bolezni predstatelnoi zhelezy, 240.

2. Haverkamp, J., Charbonneau, B., Ratliff, T. L. (2008). Prostate inflammation and its potential impact on prostate cancer: A current review. Journal of Cellular Biochemistry, 103 (5), 1344-1353. doi: 10.1002/jcb.21536

3. Filippovich, V. A. (2008). Zhurnal Grodnenskogo gosudarstvennogo meditcinskogo universiteta, 1, 93-101.

4. Pankrusheva, T. A., Erofeeva, L. N., Orlova, T. V., Kurilova, O. O., Chekmareva, M. S. (2016). Kurskii nauchno-prakticheskii vestnik "Chelovek i ego zdorove", 2, 108-112.

5. Dziuba, A. S., Trofimova, E. O. (2014). Farmatciia, 3, 27-30.

6. Orlova, T. V. (2014). Vestnik Voronezhskogo gosudarstvennogo universisteta. Seriia : Khimiia. Biologiia. Farmatciia, 1, 126-133.

7. Zaichenko, V. S., Ruban, O. A., Maslii, Ju. S., Gerbina, N. A. (2017). Justification for the Composition and Method of Active Pharmaceutical Ingredients Administration at the Development of Suppositories for the Treatment of Benign Prostate Gland Diseases. Asian Journal of Pharmaceutics, 11 (2), 129-134.

8. Bykovskii, S. N. et al. (2015). Farmatcevticheskaia razrabotka. Moscow: Pero, 472.

9. Abramovich, R. A., Vorobev, A. N., Elagina, I. A., Sinitcyna, N. I. (2012). Nauchnye vedomosti Belgorodskogo gosudarstvennogo universiteta. Seriia: Meditcina. Farmatciia, 18, 10-3 (129), 101-104.

10. Zorro, M. Dal, Franceschinis, E., Punchina, A., Realdon, N. (2012). Effect of the surfactant on the availability of piroxicam as a poorly hydrosoluble drug from suppositories. Pharmazie, 1, 37-45.

11. Orlova, T. V., Pankrusheva, T. A. (2013). Vspomogatelnye veshchestva v tekhnologii suppozitoriev i nauchno-metodicheskie podkhody $k$ ikh vyboru, 160.

12. Derzhavna Farmakopeia Ukrainy : v 3 t. (2015). Kyiv: Ukrayinskyi naukovyi farmakopeinyi tsentr yakosti likarskykh zasobiv, $1,1128$.

13. Touitou, E., Donbrow, M., Azaz, E. (2005). New hydrophilic vehicles enabling rectal and vaginal absorbtion. Drug Delivery, 1, 399-407.

14. Romanina, D. M., Gladyshev, V. V., Lisianskaia, A. P., Kechin, I. L. (2016). Aktualni pytannia farmatsevtychnoi i medychnoi nauky ta praktyky, 3 (22), $23-27$.

15. Orlova, T. V., Pankrusheva, T. A. (2014). Farmatciia, 1, 34-38.

Information about authors:

Zaychenko V., graduate student department of Industrial Technology of Drugs, national university of pharmacy.

E-mail: schweppes159753@gmail.com. ORCID - http: //orcid. org/0000-0002-3801-9853

Ruban O., Doctor of Pharmaceutical Sciences, professor, Head of the department of Industrial Technology of Drugs, national university of pharmacy.

E-mail: ruban_elen@ukr.net. ORCID - http: //orcid. org/0000-0002-2456-8210

Masliy J., Candidate of Pharmaceutical Sciences, associate professor, Head of the department of Industrial Technology of Drugs, national university of pharmacy. E-mail: julia.masliy@gmail.com. ORCID - http: //orcid. org/0000-0002-8968-0262

Gerbina N., Candidate of Pharmaceutical Sciences, assistant, Head of the department of Industrial Technology of Drugs, national university of

pharmacy. E-mail: n.a.gerbina@gmail.com. ORCID - http: //orcid. org/0000-0001-9826-7552

Відомості про авторів:

Зайченко В. С., аспірант кафедри заводської технології ліків, Національний фармацевтичний університет.

E-mail: schweppes159753@gmail.com. ORCID - http: //orcid. org/0000-0002-3801-9853

Рубан О. А., д-р фарм. наук, професор, завідувач кафедри заводської технології ліків, Національний фармацевтичний університет.

E-mail: ruban_elen@ukr.net. ORCID - http: //orcid.org/0000-0002-2456-8210

Маслій Ю. С., канд. фарм. наук, доцент кафедри заводської технології ліків, Національний фармацевтичний університет

E-mail: julia.masliy@gmail.com. ORCID - http: //orcid.org/0000-0002-8968-0262

Гербіна Н. А., канд. фарм. наук, асистент кафедри заводської технології ліків, Національний фармацевтичний університет.

E-mail: n.a.gerbina@gmail.com. ORCID - http: //orcid.org/0000-0001-9826-7552

Сведения об авторах:

Зайченко В. С., аспирант кафедры заводской технологии лекарств, Национальный фармацевтический університет.

E-mail: schweppes159753@gmail.com. ORCID - http: //orcid. org/0000-0002-3801-9853

Рубан Е. А., д-р фарм. наук, професор, заведующая кафедры заводской технологии лекарств, Национальный фармацевтический університет. E-mail: ruban_elen@ukr.net. ORCID - http: //orcid. org/0000-0002-2456-8210

Маслий Ю. С., канд. фарм. наук, доцент кафедры заводской технологии лекарств, Национальный фармацевтический університет. E-mail: julia.masliy@gmail.com. ORCID - http: //orcid. org/0000-0002-8968-0262

Гербина Н. А., канд. фарм. наук, ассистент кафедры заводской технологии лекарств, Национальный фармацевтический университет).

E-mail: n.a.gerbina@gmail.com. ORCID - http: //orcid.org/0000-0001-9826-7552

Рекомендована д. фарм. н., професором Є. В. Гладухом

Надійшла до редакції 24.10.2017 p. 